\title{
PENGEMBANGAN MODEL PEMBELAJARAN GERAK DASAR UNTUK ANAK USIA 2-4 TAHUN
}

\section{DEVELOPING A TEACHING MODEL OF BASICMOVEMENT FOR KIDS AT 2 TO 4 YEARS OLD}

\author{
Bambang Prayitno, Sukadiyanto \\ Yogyakarta International School, Universitas Negeri Yogyakarta \\ bbgpry@gmail.com, sukadiyanto_fik@yahoo.com
}

\begin{abstract}
Abstrak
Penelitian ini bertujuan untuk menghasilkan model pembelajaran gerak dasar untuk anak usia 2-4 tahun. Model pembelajaran gerak dasar disesuaikan dengan aspek pertumbuhan dan perkembangan serta karakteristik anak pada usianya yang dikemas melalui aktivitas fisik yang difokuskan pada gerak dasar lokomotor, nonlokomotor dan manipulatif. Metode yang digunakan dalam penelitian ini adalah pengembangan dengan tujuh tahapan, yaitu: (1) pengumpulan hasil riset dan informasi, (2) analisis terhadap produk yang akan dikembangkan, (3) mengembangkan produk awal, (4) validasi ahli, (5) uji coba skala kecil dan revisi, (6) uji coba skala besar dan revisi, dan (7) pembuatan produk final. Subjek penelitian ini adalah anak dengan rentang usia 2-4 tahun. Hasil penelitian ini berupa model pembelajaran gerak dasar anak usia 2-4 tahun yang berisikan tujuh aktivitas gerak, yaitu: (1) Merayap dan Merangkak, (2) Berjalan di Atas Tali, (3) Melempar Bean Bag ke dalam Simpai, (4) Bowling Games, (5) Parachute Games, (6) Memanjat, dan (7) Melompat dan Meloncat. Kesimpulan bahwa model pembelajaran yang disusun sangat sesuai dengan karakteristik serta pertumbuhan dan perkembangan gerak anak usia 2-4 tahun serta layak digunakan untuk pembelajaran gerak dasar pada Kelompok Bermain.
\end{abstract}

Kata kunci: Model pembelajaran, gerak, usia 2-4 tahun

\begin{abstract}
The aim of this study was to develop a teaching model of basic movement for children of 2 to 4 years old. The teaching model was based on their development aspect and characteristics and it was focused on three basic movements: locomotors, non locomotors, and manipulative movements. This is a research and developmental study. The development of the teaching model was conducted in seven steps: (1) collecting information, (2) information analysis, (3) developing initial product, (4) expert's validation and revision, (5) preliminary field test and revision, (6) main field test and revision, and (7) making the final product. The subject of this research was 2 to 4 year old children. The result of this study is in the form of a manual for basic movement teaching for two to-four-year-old children, that consists of seven teaching models: (1) Creeping and Crawling, (2) Walking on the Rope, (3) Throwing Bean Bag to the Hula-Hoop, (4) Bowling Games, (5) Parachute Games, (6) Climbing, and (7) Jumping. As a conclusion, the teaching model is very good and effective. From the evaluation of experts and teachers, it can be concluded that the developed model is very good and appropriate with the characteristic, growth, and development of two-to-four-year-old children`s movement.
\end{abstract}

Keywords: Teaching model, basic movement, two-to-four year-old children. 


\section{Pendahuluan}

Stimulasi pengalaman dan pengayaan berbagai keterampilan motorik pada usia dini sangat bermakna bagi perkembangan anak. Individu yang pada masa kecilnya memiliki berbagai pengalaman pola gerak dasar dan berbagai aktivitas, akan lebih mudah melakukan berbagai keterampilan motorik. Dengan demikian, pengalaman keterampilan motorik anak di masa lalu akan menjadi dasar dalam pembelajaran keterampilan motorik yang baru. Bagi anak-anak modal berbagai pengalaman keterampilan motorik di masa lalu akan bermanfaat besar dalam menjalani kehidupan pada masamasa berikutnya.

Dunia anak adalah dunia bermain, artinya semua jenis aktivitas yang ditujukan untuk mengembangkan potensi anak usia dini menggunakan bermain sebagai wahananya. Pada umumnya aktivitas bermain tentu selalu melibatkan aktivitas jasmani. Melihat dunia anak adalah dunia bermain maka melakukan proses belajar harus dengan bermain dan bermain merupakan proses belajar yang sesuai dengan tahapan perkembangan anak usia dini.

Menyadari arti penting pengalaman gerak dasar bagi anak usia dini, peneliti melakukan wawancara dengan guru Kelompok Bermain (Guru PAUD) dan melakukan kajian terhadap pembelajaran gerak yang sesuai dengan karakteristik serta tahap pertumbuhan dan perkembangan anak. Berdasarkan kajian awal terhadap pertumbuhan dan perkembangan anak, diketahui bahwa ruang lingkup pembelajaran gerak dasar terdiri atas: (1) gerak dasar lokomotor, (2) gerak dasar nonlokomotor, (3) gerak dasar manipulatif. Diketahui juga bahwa pembelajaran gerak dasar belum terlaksana dengan baik karena dalam proses pembelajaran gerak dasar masih terkonsentrasi pada motorik halus saja dan belum sesuai dengan tahap pertumbuhan dan perkembangan fisik motorik anak.

Pengembangan model pembelajaran gerak dasar untuk anak usia 2-4 tahun ini dapat mendatangkan beberapa keuntungan sekaligus karena; (1) anak dapat bermain sambil mengembangkan keterampilan jasmani, (2) anak mendapat materi aktivitas jasmani sambil bermain, (3) pengalaman gerak, dan (4) menambah wawasan guru mengenai variasi pembelajaran gerak dasar.

Pembuatan model pembelajaran gerak dasar pada anak usia 2-4 tahun harus memperhatikan gerak dasar aktivitas jasmaninya, hal ini akan lebih memudahkan anak dalam mempelajari gerak. Tahapan pertumbuhan dan perkembangan merupakan aspek yang sangat penting untuk dipertimbangkan dalam perencanaan proses pembelajaran yang akan diikutinya. Kemampuan gerak yang perlu dikembangkan pada anak usia 2-4 tahun adalah kemampuan gerak fundamental yaitu kemampuan gerak dasar $l o-$ komotor, nonlokomotor, dan manipulatif.

Memperhatikan permasalahan tersebut maka penelitian ini akan berupaya mengembangkan model pembelajaran gerak dasar yang mampu merangsang pertumbuhan dan perkembangan fisik anak anak usia 2-4 tahun. Pengembangan gerak dasar yang terdapat pada satuan pendidikan usia dini saat ini masih sebatas untuk kesenangan anak, belum banyak mempertimbangkan manfaat gerak dasar yang baik. Dapat disimpulkan bahwa dibutuhkan suatu media yang dapat menjadi jalan keluar permasalahanpermasalahan yang ada, mengingat pentingnya aktivitas jasmani untuk memberikan pengalaman gerak bagi anak usia dini. Oleh karena itu, peneliti ingin mengembangkan model pembelajaran yang mengandung berbagai bentuk aktivitas jasmani, yang dapat digunakan guru kelompok bermain/pra sekolah sebagai salah satu bentuk pembelajaran.

Sukadiyanto (2012) proses pembelajaran pada anak usia dini selalu memanfaatkan aktivitas jasmani. Adapun melalui aktivitas jasmani diharapkan membantu anak agar dapat: (1) memenuhi hasrat anak untuk bergerak, (2) mentransformasikan nilai-nilai konsep diri, apresiasi, dan budaya hidup sehat, (3) menggali dan mengembangkan kompetensi keterampilan, (4) mengembangkan kebugaran jasmani, (5) mengembangkan berbagai keterampilan terbuka (open skill) yang berorientasi pada proses aktivitas jasmani, (6) mendorong pertumbuhan dan perkembangan anak secara serasi, selaras dan seimbang.

Prinsip pembelajaran gerak bagi anak usia dini selain mengacu pada tema juga harus mempertimbangkan beberapa prinsip sebagai berikut. (1) pelaksanaan di tempat yang aman guna menjamin keselamatan anak, (2) pelaksanaan bermain di lapangan yang lunak. Contohnya rumput, pasir dan matras, (3) jenis permainan mampu menstimulasi dan mendorong optimalisasi kedua belahan otak kanan dan otak kiri, contohnya dengan gerak dan lagu, (4) jenis permainan melibatkan motorik kasar dan motorik halus, (5) jenis permainan melibatkan ekstrimitas anggota badan atas dan bawah, kiri dan 
kanan, (6) jenis permainan mencakup semua kemampuan dasar gerak fundamental, (7) jenis permainan harus mengandung unsur-unsur gerak mamalia, reptilian, dan manusia. (8) frekuensi minimal $3 \mathrm{x} /$ minggu. (9) jenis permainan harus menimbulkan rasa senang dan gembira, (10) repetisi 2-3 jenis permainan pertatap muka.

Model pembelajaran akan menjelaskan kegiatan-kegiatan yang dilakukan oleh pendidik selama pembelajaran berlangsung. Setiap pengajar atau pendidik akan mempunyai alasan-alasan kenapa menentukan sikap tertentu dalam pembelajaran. Pembelajaran harus dapat mengembangkan keseluruhan potensi siswa, seluruh potensi akan berkembang apabila siswa terbebas dari rasa takut dan menegangkan. Oleh karena itu diupayakan agar proses pembelajaran yang menyenangkan (enjoyfull learning), hal ini dapat dilakukan suatu misal menata ruangan yang menarik.

Joyce dan Weil (2004, p.7) "Model of teaching are really model of learning, as we help students acquire information, ideas, skills, value, ways of thinking, and means of expressing themselves". Model pengajaran adalah model pembelajaran. Model pembelajaran dapat membantu siswa memeroleh informasi, ide, keterampilan, nilai, cara berpikir, dan cara mengekspresikan diri. Joyce dan Weil (2004, p.25) "A model of teaching is a description of a learning environment including our behavior as teacher when that model is used", model pembelajaran adalah suatu deskripsi dari lingkungan belajar termasuk perilaku guru pada saat menggunakan model, model pembelajaran memiliki banyak kegunaan yaitu: perencanaan pembelajaran dan kurikulum untuk merancang bahan ajar, termasuk program-program multimedia.

Model pembelajaran diartikan sebagai prosedur sistematis dalam mengorganisasikan pengalaman belajar untuk mencapai tujuan belajar, dapat juga diartikan suatu pendekatan yang digunakan dalam kegiatan pembelajaran, model pembelajaran didefinisikan sebagai berikut, yaitu: (1) model pembelajaran dalam arti luas adalah suatu proses mempersiapkan secara sistematis kegiatan-kegiatan yang akan dilakukan untuk mencapai suatu tujuan tertentu, (2) model pembelajaran adalah suatu cara bagaimana mencapai tujuan sebaik-baiknya dengan sumber-sumber yang ada supaya lebih efisien dan efektif, (3) model pembelajaran adalah penentuan tujuan yang akan dicapai atau yang akan dilakukan, bagaimana, bilamana, dan siapa. Model pembelajaran gerak dasar untuk anak usia 2-4 tahun adalah sebuah model yang digunakan sebagai pedoman dalam melaksanakan kegiatan aktivitas motorik halus dan motorik kasar dengan tujuan untuk merangsang pertumbuhan dan perkembangan anak secara optimal serta untuk memberikan pengalaman belajar gerak pada anak. Konsep pembelajaran gerak dasar untuk anak usia 2-4 tahun di susun berdasarkan unsur gerak mamalia, reptilian dan manusia, bentuk aktivitas belajar gerak dalam model ini memperhatikan karakteristik dan tahapan tumbuh kembang anak di usianya maka gerakan-gerakan yang dipilih adalah gerakan yang sudah dikenal oleh anak seperti berjalan, berlari, melompat, merangkak, memanjat dan melempar, selain itu belajar gerak pada anak harus dilakukan sambil bermain atau bermain sambil belajar. Metode pembelajaran gerak dasar untuk anak usia 2-4 tahun berdasarkan urutannya yaitu latihan pendahuluan (pemanasan), latihan inti, dan latihan pendinginan.

Pedoman praktis bagi guru untuk melaksanakan model pembelajaran gerak dasar untuk anak usia 2-4 tahun sebagai berikut:

Urutan langkah-langkah pembelajaran (syntax): (a) Latihan pendahuluan (pemanasan), untuk menyiapkan tubuh anak untuk melaksanakan latihan inti, (b) Latihan inti (aktivitas gerak; merayap dan merangkak, berjalan di atas tali, melompat dan meloncat, memanjat, permainan parasut, permainan bowling, melempar bean bag ke dalam simpai). Setiap latihan inti guru dapat menggunakan 3-4 jenis aktivitas gerak yang dipilih berdasarkan komponen keterampilan gerak yang akan dicapai yaitu gerak lokomotor, nonlokomotor dan manipulatif), (c) Latihan penutup (pendinginan) gerakan mengatur napas untuk mengembalikan ke kondisi normal atau kondisi sebelum latihan gerak.

\section{Sistem Sosial}

Sistem sosial, (a) dilakukan sambil bermain dan belajar atau sebaliknya; (b) Belajar berpusat pada anak dan guru; (c) Berawal dari yang dimiliki anak (pengalaman belajar sudah dikenal oleh anak); (d) Menggunakan alam sebagai sarana belajar; (e) Membekali keterampilan hidup (mandiri dan bertanggung jawab terhadap diri sendiri); (f) Student active learning (memberikan kesempatan untuk aktif dan antusias)

\section{Prinsip-prinsip Reaksi}

Prinsip-prinsip reaksi, yaitu: (a) Mengandung unsur-unsur gerak mamalia, reptilian, 
dan manusia; (b) Gerakan yang sederhana ke kompleks (mudah-sulit); (c) Gerak yang menyenangkan; (d) Mengandung unsur yang sudah di kenal oleh anak, seperti berjalan, melompat; (e) Frekwensi belajar 3x/minggu, pengulangan gerakan 2-3 kali setiap tatap muka pembelajaran; (f) Berdasarkan karakteristik pertumbuhan dan perkembangan fisik motorik anak di usia 24 tahun.

\section{Sistem Pendukung}

Pertama, pengelolaan kelas (dimana dilaksanakan/tempat belajar, persiapan peralatan, petunjuk pelaksanaan, teknis pemasangan alat, menyiapkan anak seperti membariskan, menjelaskan aturan pembelajaran.

Kedua, fasilitas belajar seperti indoor room ditunjang dengan kelengkapan alat seperti adanya matras/kasur, alat tidak membahayakan anak, contohnya di lapangan atau di halaman sekolah yang lunak untuk pembelajaran.

Masa kanak-kanak usia 2-4 tahun diperlukan media pembelajaran yang mengembangkan fisik motorik anak yang sesuai dengan karakteristik dan tahapan tumbuh kembang anak yaitu anak sangat aktif mengeksplorasi lingkungan sekitar, menunjukkan perkembangan bahasa dan emosi, anak sangat aktif melakukan berbagai kegiatan memanjat, melompat, berlari, berjalan, meloncat, melempar dan menangkap (perkembangan fisik motorik), pertumbuhan ukuran bentuk tubuh yang berkaitan dengan mekanisme otot, syaraf serta keterampilan motorik (pertumbuhan fisik), melalui model pembelajaran gerak yang berisikan bermacammacam aktivitas fisik menjadi pengalaman dan pengkayaan gerak bagi anak.

Pembelajaran gerak dasar perlu diperhatikan dalam pengelolaan kelas supaya tidak terjadi kecelakaan dan aman bagi siswa untuk melakukan gerak, dalam pengelolaan gerak guru memperhatikan keselamatan dan kenyamanan belajar seperti tempat atau lokasi belajar, persiapan peralatan, petunjuk pelakasanaan gerak, teknis pemasangan alat, menyiapkan anak sebelum aktivitas seperti membariskan, memberikan informasi yang jelas, adanya aturan belajar dan bermain sehingga siswa dan guru siap untuk melaksanakan pembelajaran gerak.

Aktivitas gerak motorik pada anak usia 2-4 tahun yang dijadikan sebagai model pembelajaran gerak sangat bermanfaat bagi anak di PAUD terutama pada usia prasekolah dan kelompok bermain, melalui model belajar tersebut digunakan untuk melatih: (1) gerak motorik anak yaitu: motorik halus (menggunakan otototot halus seperti melempar melempar, menangkap, berpegangan pada memanjat dan bermain parasut), dan motorik kasar (menggunakan otot besar seperti melompat, meloncat, berjalan, merayap, merangkak), (2) melatih kesadaran gerak (movement awareness) dengan pembelajaran keterampilan gerak lokomotor (merayap, merangkak, melompat, meloncat, berjalan), nonlokomotor (melempar pada bowling, permainan parasut, memanjat, dan manipulatif (berjalan, memanjat, melempar bola, permainan parasut).

\section{Teori Belajar Gerak}

Schmidt (2005, p.420) menyatakan bahwa teori belajar motorik (gerak) yang dikembangkan oleh Adams (closed-loop theory) dan selanjutnya teori schema yang dikembangkan oleh Schmidt, prinsip dasar kedua teori ini adalah sistem pengontrolan gerak terbuka dan tertutup.

\section{Teori Adam (Closed-Loop Theory)}

Teori belajar mendorong Adams untuk mengembangkan teori belajar motorik yang biasa disebut sistem tertutup yang penekanannya pada umpan balik (feedback) yang dicocokkan dengan mekanisme rujukan benar salahnya suatu gerakan, artinya gerakan yang telah dilakukan seseorang dibandingkan dengan suatu kriteria, mekanisme rujukan beroperasi dengan sistem tertutup tetapi kemudian sebagai sebuah sistem terbuka yang mengirimkan semua informasi yang dibutuhkan untuk memulai suatu gerakan.

Adam (Schmidt, 2005, p.411) menjelaskan bahwa siswa mengembangkan kapabilitas mendeteksi error setelah suatu gerakan selesai dilakukan, seseorang akan membandingkan umpan balik yang diterimanya dengan jejak perseptual, dan perubahan yang terjadi merupakan error yang ditanggapi oleh siswa yang bersangkutan. Pengarahan gerak ke arah target yang dituju dapat menghasilkan perubahan karena umpan balik terus menerus menambah jejak perceptual.

Konsep jejak perseptual memungkinkan seseorang dapat: (1) menentukan letak anggota badannya dengan benar, (2) sebagai dasar untuk mengetahui seberapa jauh suatu gerakan meleset dari tempat yang ditetapkan setelah keseluruhan gerak selesai dilakukan. 


\section{Teori Schmidt (Schema Theory)}

Schmidt (2005, p.413) menjelaskan bahwa teori schema (skema) adalah dua keadaan memori yaitu: (1) recall memory yang bertanggung jawab untuk menghasilkan gerakan, (2) recognition memory yang bertanggung jawab untuk mengevaluasi respons gerak. Contoh dalam gerakan balistik memori re-call terlibat dengan program motorik dan parameter, jauh sebelumnya untuk melaksanakan suatu gerakan dengan keterlibatan yang amat minim dari umpan balik peripheral, sedangkan memori rekognisi adalah sistem sensoris yang berkemampuan untuk mengevaluasi respons yang dihasilkan umpan balik setelah suatu gerakan selesai dilaksanakan.

Kogan (2004, p.31) gerak lokomotor adalah gerak dari seluruh tubuh melalui ruangan atau jarak tertentu seperti gerak berjalan, berlari, melompat, gerak nonlokomotor adalah gerak di mana hanya bagian tubuh yang bergerak seperti mengayun dan memutar lengan, mendorong, menarik, mencondongkan badan. Malina (2004, p.196) gerak manipulatif adalah gerak di mana objeknya bergerak seperti dalam lempar, tangkap, menggiring, menendang dan variasi dari gerak tersebut di atas, konsep dasar yang perlu diperhatikan dalam pembelajaran gerak di PAUD adalah bagaimana para guru PAUD memahami pola perkembangan motorik anak dan bagaimana sistematika pembelajarannya merupakan hal yang harus dipahami dan dilaksanakan, di bawah ini disajikan bagaimana gerakan-gerakan dasar sebagai fondasi menuju ke tahap selanjutnya, dari gambar tersebut gerak dasar lokomotor, nonlokomotor dan manipulatif merupakan fondasi utama untuk menanamkan kesadaran gerak (movement awareness) menjadi fondasi keterampilan gerak.

Pola pendasaran gerak inilah yang memegang peran penting dalam melaksanakan pembelajaran motorik di sekolah dan bagaimana guru membimbing siswanya dari gerak dasar menuju proses pembelajaran gerak selanjutnya, pengalaman gerak yang baik pada masa kecil, merupakan modal yang sangat berarti bagi pengembangan gerak selanjutnya.

Kogan (Lumintuarso, 2011, p.24) menerangkan gerak lokomotor secara sederhana yaitu: "go some where" yaitu bergerak melintasi ruang dan jarak dengan berlari, skipping, melompat, berjalan, berjingkat dan sebagainya. Setiap gerak yang melintasi ruang merupakan gerak lokomotor, adapun beberapa menu gerak lokomotor yang dapat diberikan sebagai gerak dasar adalah sebagai berikut:

Kogan (Lumintuarso, 2011, p.32) Gerak nonlokomotor adalah gerak yang melibatkan anggota tubuh atau bagian batang tubuh yang bergerak mengelilingi porosnya Gerak nonlokomotor merupakan gerak di mana hanya bagian tubuh tertentu yang bergerak seperti mengayun dan memutar lengan, mendorong, menarik, gerak berputar pada balet, berayun, membungkuk, meregang, mengulur. Kogan (Lumintuarso, 2011, p.32) memberi batasan sederhana: "movements are those that stay in one place" Hal ini berarti bahwa tidak seperti gerak lokomotor, gerak nonlokomotor dilakukan di tempat tidak melakukan perpindahan salah satu titik tumpu. Berikut adalah katalog dari gerak nonlokomotor:

Gerak manipulatif adalah gerak di mana objeknya bergerak, contoh dalam lempar, tangkap, menggiring, menendang dan variasi gerakan gerak tersebut adalah lempar, tangkap, tending, memukul.

\section{Pertumbuhan Anak Usia 2 Tahun.}

Erikson (Allen dan Lynn, 2008, p.112) menyatakan bahwa hal tersebut mengakibatkan pergulatan dari waktu ke waktu ketika anak mencoba mengambil sikap terhadap keinginan yang bertentangan antara mandiri (otonomi) atau ketergantungan.

\section{Pertumbuhan dan Ciri-Ciri Fisik}

Pertumbuhan dan ciri-ciri fisik, yaitu: (1) Berat badan naik rata-rata 0,9 sampai $1,1 \mathrm{~kg}$ per tahun; berat badannya kurang lebih 11,8 sampai $14,5 \mathrm{~kg}$ atau sekitar 4 kali lipat berat lahir; (2) Tumbuh lebih tinggi kurang lebih 7,6 sampai $12,7 \mathrm{~cm}$ per tahun; rata-rata tinggi badannya 86,3 sampai $96,5 \mathrm{~cm}$; (3) Postur tubuhnya semakin tegak, perutnya masih besar dan menonjol, punggung melengkung karena otot perut belum berkembang sempurna; (4) Pernapasan lambat dan teratur (kira-kira 20 sampai 35 kali permenit); (5) Suhu tubuh mulai naik turun tergantung pada aktivitas, keadaan emosi dan lingkungan; (6) Otak mencapai $80 \%$ dari ukuran orang dewasa; (7) Tumbuhnya gigi hampir lengkap; geraham kedua muncul, dengan jumlah total dua puluh gigi susu atau gigi "bayi".

\section{Perkembangan Motorik}

Perkembangan Motorik yaitu: (1) Berjalan dengan lebih tegak, menapak dari tumit ke 
jari kaki; mampu memutari rintangan yang menghalangi jalannya; (2) Berlari dengan kepercayaan diri yang lebih besar, lebih jarang terjatuh; (3) Jongkok untuk jangka waktu yang lama ketika bermain; (4) Naik tangga tanpa dibantu (tetapi tidak dengan kaki secara bergantian) pegangan pada pinggiran tangga untuk mendukung tubuhnya; (5) Bisa menjaga keseimbangan tubuh dengan berdiri di atas satu kaki (hanya sebentar) melompat naik dan turun, tetapi bisa terjatuh; (6) Mulai bisa memberi tahu kalau mau buang air (tergantung pada perkembangan fisik anak dan syaraf), walaupun kadang-kadang masih mengompol; (7) Melempar bola besar dengan ayunan rendah tanpa kehilangan keseimbangan; (8) Memegang cangkir atau gelas (pastikan terbuat dari bahan yang tidak bisa pecah) dengan satu tangan; (9) Membuka kancing besar, membuka ritsleting besar; (10) Membuka pintu dengan memutar gagang pintu; (11) Menggenggam krayon besar di kepalan tangannya, mencorat-coret dengan antusias di atas kertas yang lebar; (12) Memanjat ke atas kursi, memutar badannya dan duduk; (13) Menyukai kegiatan menuang dan mengisi pasir, air, butir-butiran Styrofoam; (14) Menumpuk empat sampai enam benda; (15) Mengendarai mainan beroda dan menggunakan kaki untuk mengayuhnya.

\section{Pertumbuhan Anak Usia Tiga Tahun}

Anak usia tiga tahun cenderung untuk tenang, santai dan bisa bekerja sama. Konflik dengan Killen dan Smetana (Allen dan Lynn, 2008, p.127) menyatakan bahwa anak usia tiga tahun biasanya mau mematuhi perintah orang dewasa. Anak usia ini mampu menunda kegembiraan; kebutuhan untuk mendapatkan apa yang diinginkan "sekarang juga" sudah berkurang. Anak di usia ini menemukan kegembiraan dalam dirinya dan kehidupan secara umum dan menunjukkan dorongan yang tidak tertahankan untuk mengetahui segala sesuatu di dunia sekitarnya.

\section{Pertumbuhan dan Ciri-Ciri Fisik}

Pertumbuhan dan ciri-ciri fisik anak usia 3 tahun yaitu: (1) Pertumbuhan terus berjalan, walaupun lebih lambat, selama dua tahun pertama; (2) Tinggi badan meningkat 5 sampai $7,6 \mathrm{~cm}$ per tahun; rata-rata tinggi badan 96,5 sampai 101,6 cm, hampir dua kali lipat tinggi badan bayi; (3) Tinggi badan ketika de-wasa dapat diprediksikan dari ukuran tinggi anak usia tiga tahun; laki-laki kurang lebih 53 persen dari tinggi orang dewasa; perempuan 57 persen dari tinggi orang dewasa; (4) Berat badan bertambah 1,4 sampai $2,3 \mathrm{~kg}$ per tahun; rata-rata berat badan 30 sampai 38 pon $(13,6-17,2 \mathrm{~kg})$; (5) Kecepatan denyut nadi rata-rata 90 sampai 100 kali permenit; (6) Kecepatan pernapasan 20 sampai 30, tergantung pada jenis kegiatan; anak terus bernapas dengan menggunakan perut; (7) Suhu tubuh rata-rata 35,5 derajat Celcius sampai 37,4 derajat celcius: dipengaruhi oleh kelelahan, penyakit dan stress; (8) Kaki tumbuh lebih cepat daripada lengan tangan; menjadikan anak usia tiga tahun lebih tinggi dan kurus, seperti penampilan orang dewasa; (9) Lingkar dada dan kepala sama; ukuran kepala lebih proporsional untuk tubuh; (10) Leher semakin panjang karena 'lemak bayi' menghilang; (11) Postur tubuh semakin tegak; perut tidak lagi menonjol; (12) Kaki masih kelihatan agak pengkar keluar; (13) Memunyai satu susunan gigi "bayi" yang utuh; (14) Membutuhkan komsumsi kurang lebih 1500 kalori sehari.

\section{Perkembangan Motorik}

Perkembangan Motorik anak usia 3 tahun yaitu: (1) Naik turun tangga tanpa dibantu dengan menggunakan kaki kanan dan kiri secara bergantian; bisa melompat dari undakan yang terendah, mendarat dengan kedua kaki; (2) Berdiri seimbang dengan satu kaki untuk jangka waktu yang pendek; (3) Menendang bola besar; (4) Makan sendiri, membutuhkan sedikit bantuan; (5) Meloncat ditempat; (6) Mengayuh sepeda kecil beroda tiga atau beroda besar; (7) Menangkap bola yang dilempar dengan kedua tangan direntangkan; (8) Senang main ayunan (tidak terlalu tinggi atau cepat); tertawa, dan minta diayun; (9) Menunjukkan pengendalian yang lebih baik terhadap krayon atau spidol; membuat coretan mendatar, tegak lurus dan melingkar; (10) Memegang krayon atau spidol di antara telunjuk dan tengah dengan ibu jari (genggaman kaki tiga), tidak digenggam seperti tahap sebelumnya; (11) Membalik halaman buku satu persatu; (12) Senang menyusun bangunan dengan menggunakan balok; (13) Membangun menara balok tingkat delapan atau lebih; (14) Senang bermain dengan lempung; menghaluskan, menggulung dan memipihkan; (15) Mulai menunjukkan dominasi tangan; (16) Membawa wadah yang berisi air, seperti gelas susu atau mangkuk air, tanpa banyak tumpah; menuangkan cairan dari gelas tuang ke wadah yang lain; (17) Memakai dan melepas kancing besar dan ritsleting pada pakaian; (18) 
Mencuci tangan dan mengeringkannya; menggosok gigi sendiri, tetapi tidak tuntas; (19) Bisa benar-benar mengendalikan buang air kecil hampir setiap waktu pada tahap ini.

Pertumbuhan Anak Usia 4 Tahun

Allen dan Lynn (2008, p.139) menyatakan bahwa energi yang melimpah; gagasan yang meluap-luap, obrolan dan aktivitas yang tidak ada lelahnya, kesemuanya ini adalah ciriciri anak usia empat tahun pada umumnya. Pertengkaran yang disebabkan oleh sifat keras kepala, maka perbedaan pendapat antara anak dan orang dewasa sering terjadi, anak sering menguji batasan, penuh percaya diri menegaskan kebutuhan yang semakin besar untuk mandiri. Banyak anak yang sering berteriak keraskeras, berisik, bahkan suka berkelahi; merupakan pengujian kesabaran orang dewasa dengan ucapan yang bodoh, gurauan yang menjengkelkan, obrolan yang terus menerus, dan pertanyaan yang tidak ada habisnya. Sementara itu, anak pada usia ini juga memiliki banyak sifat yang menyenangkan. Antusias, berusaha keras untuk bisa membantu, mempunyai imajinasi yang hidup, dan membuat rencana dalam batasan tertentu, contohnya "nanti sampai rumah, aku akan menggambar untukmu".

\section{Pertumbuhan dan Ciri-Ciri Fisik}

Pertumbuhan dan ciri-ciri fisik anak usia 4 tahun yaitu: (1) Berat badan bertambah kira-kira 4 sampai 5 pon $(1,8-2,3 \mathrm{~kg})$ per tahun, rata-rata berat badannya $32-40$ pon $(14,5-18,2$ $\mathrm{kg}$ ); (2) Bertambah tinggi badannya 2 sampai 2, 5 inci $(5,0-6,4 \mathrm{~cm})$ per tahun: kurang lebih tingginya 40-45 inci (101,6-114 cm); (3) Kecepatan denyut nadi kira-kira 90-110 kali permenit; (5) Kecepatan pernapasan berkisar dari 20 sampai 30, tergantung aktivitas dan keadaan emosi; (6) Suhu tubuh berkisar antara 98 derajat $\mathrm{F}$ sampai 99,4 derajat $\mathrm{F}$ (36,6 derajat Celcius sampai 37,4 derajat Celcius); (7) Lingkar kepala biasanya tidak diukur dari penggunaan suara dan bahasa yang tepat dari anak terhadap pertanyaan dan instruksi; (8) Ketajaman penglihatannya 20/30 seperti yang diukur dari tabel mata Snellen.

\section{Perkembangan Motorik}

Perkembangan Motorik anak usia 4 tahun yaitu: (1) Berjalan pada garis yang lurus (gambarlah garis lurus dengan menggunakan kapur dan lantai); (2) Melompat dengan satu kaki; (3) Mengayuh dan mengemudikan mainan beroda dengan percaya diri; belok di pojokan, menghindari rintangan dan kendaraan lain yang lewat; (4) Menaiki tangga, memanjat pohon dan mainan yang bisa di panjat di taman bermain; (5) Melompat setinggi 5 atau 6 inci (12,5 sampai $15 \mathrm{~cm}$ ); mendarat dengan kedua kaki bersama-sama; (6) Berlari, memulai, berhenti dan bergerak mengelilingi rintangan dengan mudah; (7) Melempar bola dengan ayunan atas; dengan jangkauan dan ketepatan yang semakin baik; (8) Membangun menara dengan sepuluh balok atau lebih; (9) Membentuk benda atau sesuatu dari lempung; kue, ular, hewan sederhana; (10) Meniru menggambar beberapa bentuk dan menulis beberapa huruf; (11) Memegang krayon atau spidol dengan menggunakan genggaman kaki tiga; (12) Mewarnai dan menggambar dengan tujuan tertentu; bisa mempunyai sebuah gagasan di kepalanya tetapi sering masih bermasalah dalam mewujudkannya, lalu menyebut hasil kreasinya sebagai gambar lain; (13) Semakin akurat dalam memukul paku dan pasak dengan palu; (14) Merangkai manik-manik kayu kecil dengan benang.

Kelompok Bermain (play group) adalah salah satu bentuk pendidikan anak usia dini jalur pendidikan nonformal yang memberikan layanan pendidikan bagi anak usia 2-6 tahun, untuk membantu pertumbuhan dan perkembangan anak, agar kelak siap memasuki pendidikan lebih lanjut (prioritas anak usia dua tahun sampai empat tahun).

Adi, dkk (2007, p.2) kelompok bermain sering juga disebut play group. Dari situ jelas bahwa di kelompok bermain anak distimulasi perkembangannya melalui kegiatan bermain yang menyenangkan dan memotivasi anak untuk terus mencoba, berlatih dan berkembang. Kelompok bermain merupakan tempat bermain dan belajar bagi anak sebelum memasuki Taman Kanak-kanak.

\section{Metode}

Penelitian ini menggunakan pendekatan pengembangan. Waktu penelitian dilakukan pada bulan 25 Februari 2013 di YIS dan 10-20 Maret 2013 di YIS, KB Negeri 2 Yogyakarta, PAUD Bina Buah Hati DIY. Subjek penelitian ini adalah anak dengan rentang usia 2-4 tahun. Uji coba skala kecil dilakukan terhadap delapan siswa prasekolah Yogyakarta International School. Uji coba skala besar dilakukan terhadap 24 siswa Kelompok Bermain Negeri 2 Yogyakarta dan KB PAUD Bina Buah Hati DIY. Instrumen pengumpulan data yang digunakan yaitu: (1) pedoman wawancara, dan (2) pedo- 
man observasi pembelajaran. Teknik analisis data yang dilakukan yaitu analisis deskriptif kuantitatif dan analisis deskriptif kualitatif.

Prosedur pengembangan merupakan langkah-langkah yang harus diikuti sebelum mengasilkan sebuah produk, langkah-langkah penelitian pengembangan menurut Borg \& Gall (1983, p.775) mengemukakan bahwa dalam melakukan penelitian pengembangan terdapat 10 langkah yang harus ditempuh, yaitu: (1) pengumpulan informasi, (2) perencanaan, (3) mengembangkan produk awal, (4) uji coba awal, (5) revisi untuk menyusun produk utama, (6) uji coba lapangan utama, (7) revisi untuk menyusun produk operasional, (8) uji coba produk operasional, (9) revisi produk final, dan (10) diseminasi dan implementasi produk hasil pengembangan.

Langkah-langkah tersebut diadaptasi menjadi tujuh (7) rancangan prosedur penelitian pengembangan yaitu: (1) pengumpulan informasi, (2) analisis produk yang dikembangkan, (3) mengembangkan produk awal, (4) validasi ahli, (5) uji coba skala kecil, (6) uji coba skala besar, (7) pembuatan produk akhir. Penelitian pengembangan adalah penelitian yang berorientasi pada produk maka untuk langkah penelitian ini cukup dengan tujuh langkah. Sepuluh langkah penelitian pengembangan selanjutnya bisa dikembangkan dalam pembuatan disertasi dan melakukan penelitian tindakan kelas atau penelitian eksperimen.

Data yang digunakan dalam penelitian ini berupa data kualitatif dan data kuantitatif. Jenis Data kualitatif berasal dari: (a) hasil wawancara dengan guru Kelompok Bermain, (b) data masukan ahli materi dan guru pelaku uji coba terhadap model pembelajaran. Data kuantitatif diperoleh dari hasil observasi pembelajaran yang berupa lembar penilaian terhadap model pembelajaran.

Instrumen pengumpulan menggunakan pedoman observasi dan pedoman wawancara. Observasi dilakukan untuk mendapatkan atau menjaring informasi dari para ahli untuk memberikan masukan dan saran tentang produk yang akan dihasilkan tentang pelaksanaan proses pembelajaran gerak dasar pada usia anak 2-4 tahun. Teknik analisis data yang dilakukan yaitu analisis deskriptif kuantitatif dan analisis deskriptif kualitatif. Analisis deskriptif kuantitatif dilakukan untuk menganalisis data-data berikut: (1) data skala nilai hasil penilaian para ahli materi terhadap draf model pembelajaran sebelum pelaksanaan uji coba di lapangan, (2) data hasil observasi para ahli terhadap model pembelajaran. Sementara analisis deskriptif kualitatif dilakukan terhadap: (1) data hasil wawancara dengan guru Kelompok Bermain saat studi pendahuluan, (2) data masukan terhadap model pembelajaran baik sebelum uji coba maupun setelah uji coba di lapangan.

\section{Hasil Penelitian dan Pembahasan}

Untuk mengetahui permasalahan-permasalahan pembelajaran yang terjadi di lapangan terutama berkaitan dengan aktivitas gerak dasar anak pada usia 2-4 tahun, serta bentuk pemecahan dari permasalahan tersebut, maka perlu dilakukan analisis kebutuhan. Kegiatan ini dilakukan dengan cara menganalisis proses pembelajaran yang terjadi sesungguhnya di lapangan, melakukan observasi pembelajaran dan melakukan studi pustaka/kajian literatur. Data uji coba merupakan data yang dihasilkan dari penilaian para ahli dan praktisi yang terkait dengan materi terhadap produk yang dihasilkan.

Berdasarkan uraian di atas, maka peneliti memutuskan untuk mengembangkan model pembelajaran gerak dasar untuk anak usia 2-4 tahun. Peneliti mengharapkan produk yang dihasilkan kelak dapat: (1) Memaksimalkan kemampuan serta potensi belajar gerak dasar anak di usianya sehingga dapat merangsang pertumbuhan dan perkembangan anak secara baik, (2) Menjadi acuan guru PAUD dalam memberikan pembelajaran gerak dasar sehingga kegiatan belajar menjadi lebih bervariasi dan menyenangkan, (3) Membantu bagi guru dalam membuat rencana pembelajaran yang terfokus pada gerak atau gerak motorik, (4) Mengembangkan model pembelajaran gerak dasar anak pada usia 2-4 tahun yang dengan karakteristik dan tahapan pertumbuhan dan perkembangan anak di usianya.

Tabel 1. Kategorisasi Model Pembelajaran Gerak Dasar untuk Anak Usia 2-4 Tahun

\begin{tabular}{clc}
\hline No & \multicolumn{1}{c}{ Skor } & Kategori Penilaian \\
\hline 1 & Sama atau lebih besar & Sangat sesuai \\
& dari 40 & Sesuai \\
2 & 30 sampai 39 & Cukup sesuai \\
3 & 20 sampai 29 & Tidak sesuai/Sangat \\
4 & Kurang dari 20 & tidak sesuai \\
\hline
\end{tabular}

Keterangan: (1) Skor batas bawah kategori sangat sesuai atau sangat efektif adalah: 0 , $80 \times 50=40$, dan batas atasnya adalah $50,(2)$ Skor batas bawah pada kategori sesuai atau 
efektif adalah: $0,60 \times 50=30$, dan skor batas atasnya adalah 39, (3) Skor batas bawah pada kategori cukup sesuai atau cukup efektif adalah: $0,40 \times 50=20$, dan batas atasnya adalah 29 , (4) Skor yang tergolong pada kategori sangat tidak sesuai atau sangat tidak efektif adalah: kurang dari 20.

Tabel 2. Data Rekapitulasi Skala Nilai Draf Produk Awal dari Para Ahli dan Guru.

\begin{tabular}{clccc}
\hline No & \multicolumn{1}{c}{ Kegiatan } & A1 & A2 & G \\
\hline 1 & Merayap dan Merangkak & 45 & 46 & 41 \\
2 & Berjalan di Atas Tali & 44 & 44 & 41 \\
3 & Melempar Bean Bag ke & 45 & 45 & 42 \\
& dalam Simpai & & & \\
4 & Memanjat & 41 & 44 & 45 \\
5 & Permainan Parasut & 41 & 45 & 39 \\
6 & Permainan Bowling & 43 & 46 & 43 \\
7 & Meloncat dan Melompat & 46 & 46 & 42 \\
& Skor & $\mathbf{3 0 5}$ & $\mathbf{3 1 6}$ & $\mathbf{2 9 3}$ \\
& Mean & $\mathbf{4 3 , 5}$ & $\mathbf{4 5 , 1}$ & $\mathbf{4 1 , 8}$ \\
& Persentasi & $\mathbf{8 7 \%}$ & $\mathbf{9 0 \%}$ & $\mathbf{8 4 \%}$ \\
\hline
\end{tabular}

Keterangan:

A: Ahli (expert judgement)

G: Guru (praktisi)

Ahli validasi memberikan masukan untuk menambahkan satu model sehingga jumlah model menjadi 7 pembelajaran, hal ini karena dirasa kurang cukup maka untuk model pembelajaran yang terakhir adalah model pembelajaran melompat dan meloncat. Sebelum dilakukan uji coba skala kecil terhadap produk awal, produk harus mendapat validasi dari para ahli, yaitu: (1) pakar pendidikan jasmani anak usia dini yaitu Prof. Dr. Suharjana, M.Kes, (2) pakar pembelajaran anak usia dini yaitu Dr. Pamuji Sukoco, dan (3) pakar pendidikan anak usia dini yaitu Fajar Ina, S.S.

Pada proses validasi, para ahli materi menilai dan memberi masukan terhadap produk awal. Berdasarkan hal tersebut, dilakukan revisi terhadap produk awal. Proses revisi ini terus dilakukan sampai produk awal mencapai batas nilai tertentu yang telah ditetapkan, yang menunjukkan bahwa produk awal tersebut valid dan layak diujicobakan.
Tabel 3. Data Hasil Observasi Uji Coba Skala Kecil

\begin{tabular}{llrrr}
\hline No & \multicolumn{1}{c}{ Kegiatan } & A1 & A2 & \multicolumn{1}{c}{ G 1 } \\
\hline 1 & Merayap dan & 47 & 47 & 44 \\
& Merangkak & & & \\
2 & Berjalan di Atas Tali & 47 & 47 & 45 \\
3 & Melempar Bean Bag & 45 & 47 & 46 \\
& ke dalam Simpai & & & \\
4 & Memanjat & 44 & 46 & 45 \\
5 & Permainan Parasut & 45 & 45 & 44 \\
6 Permainan Bowling & 46 & 47 & 45 \\
7 & Meloncat dan & 49 & 48 & 47 \\
& Melompat & & & \\
& Skor & $\mathbf{3 2 3}$ & $\mathbf{3 2 7}$ & $\mathbf{3 1 6}$ \\
& Mean & $\mathbf{4 6 , 1}$ & $\mathbf{4 6 , 7}$ & $\mathbf{4 5 , 1}$ \\
& Persentasi & $\mathbf{9 2 , 2 \%}$ & $\mathbf{9 3 , 4 \%}$ & $\mathbf{9 0 , 2 \%}$ \\
\hline
\end{tabular}

Keterangan:

A: Ahli (expert judgment)

G: Guru (praktisi)

Pada tahap uji skala kecil ini Fajar Ina, S.S adalah guru utama dalam pelaksanaan pembelajaran gerak dasar sedangkan Dewi Yuniversanti sebagai guru yang membantu pada kelas preschool YIS. Dari data tersebut di atas, dapat diketahui bahwa seluruh observer menyatakan draf yang ditawarkan memenuhi item observasi dalam uji coba skala kecil. Hal ini dapat dilihat dari skor atau jumlah batas bawah adalah 40 dan skor maksimal adalah 50. Sedangkan dari data tersebut dapat identifikasi berada pada rentang di atas batas bawah. Item observasi setiap model dapat dinyatakan sesuai untuk pembelajaran gerak dasar anak usia 2-4 tahun.

Tabel 4. Data Hasil Observasi Uji Coba Skala Besar

\begin{tabular}{clcccc}
\hline No & Kegiatan & A1 & A2 & G1 & G2 \\
\hline 1 & $\begin{array}{l}\text { Merayap dan } \\
\text { Merangkak }\end{array}$ & 47 & 49 & 50 & 45 \\
2 & $\begin{array}{l}\text { Berjalan di } \\
\text { Atas Tali }\end{array}$ & 48 & 47 & 40 & 44 \\
3 & $\begin{array}{l}\text { Melempar } \\
\text { Bean Bag ke } \\
\text { dalam }\end{array}$ & 49 & 48 & 40 & 47 \\
& Simpai & & & & \\
4 & Memanjat & 48 & 47 & 47 & 44 \\
5 & Permainan & 49 & 48 & 44 & 47 \\
& Parasut & & & & \\
6 & Permainan & 49 & 47 & 45 & 45 \\
& Bowling & & & & \\
7 & Meloncat \& & 49 & 48 & 49 & 46 \\
& Melompat & & & & \\
& Skor & 339 & 334 & 315 & 318 \\
& Mean & 48,4 & 47,7 & 45 & 45,4 \\
& Persentasi & $96,8 \%$ & $95,4 \%$ & $90 \%$ & $90,8 \%$ \\
\hline
\end{tabular}


Keterangan:

A: Ahli (expert judgement)

G: Guru (praktisi)

Hasil penilaian observasi dalam uji coba skala besar dapat diketahui bahwa model yang telah direvisi dari hasil uji coba skala kecil semakin menunjukkan kesesuaian dengan harapan, yaitu kesepakatan antarpakar dan guru PAUD serta ketetapan dan ketepatan hasil observasi terhadap model pembelajaran gerak dasar untuk anak usia 2-4 tahun yang sangat sesuai. Hal ini dapat dilihat dari rata-rata skor penilaian observasi dan persentase kesesuaian model pembelajaran.

\section{Simpulan dan Saran}

Berdasar pada hasil penelitian, maka dapat diambil suatu kesimpulan yaitu, tersusun model pembelajaran gerak dasar anak usia 2-4 tahun yang terdiri atas tujuh aktivitas pembelajaran yaitu: (1) Merayap dan Merangkak, (2) Berjalan di atas Tali, (3) Melempar bean bag ke dalam simpai, (4) Bowling Games, (5) Memanjat, (6) Parachute Games, dan (7) Melompat dan Meloncat.

Dari hasil penilaian para pakar dan guru terhadap model pembelajaran yang dikembangkan, disimpulkan bahwa model pembelajaran yang disusun sangat sesuai dengan karakteristik serta pertumbuhan dan perkembangan anak pada usia 2-4 tahun yang ditunjukan oleh hasil observasi antara pakar dan praktisi. Oleh karena itu, dapat disimpulkan bahwa model pembelajaran yang dikembangkan layak digunakan.

Berdasarkan pertanyaan penelitian yang sudah dibuat maka hasil penelitian ini menjawab permasalahan yaitu: (1) proses pembelajaran gerak dasar terdiri atas tiga aspek adalah gerak dasar lokomotor, nonlokomotor dan manipulatif merupakan fondasi utama untuk menanamkan kesadaran gerak (movement awareness). Pembelajaran gerak dasar melihat dari gerakan mamalia dan hewan seperti memanjat, merangkak dan merayap. Pembelajaran gerak dasar mengacu pada prinsip pembelajaran fisik motorik anak usia dini. (2) model pembelajaran gerak dasar sesuai dengan pertumbuhan dan perkembangan anak usia 2-4 tahun, ditunjukkan dengan adanya jenis kegiatan yang mengandung unsur pengembangan otot-otot kecil maupun besar, bentuk dan ukuran tubuh anak serta perkembangan motorik, (3) model pembelajaran gerak dasar membuat siswa lebih aktif dan senang karena aktivitas jasmani tersebut dapat memfasilitasi dan mengeksplorasi anak terhadap kegiatan yang ada di sekitarnya dengan di tunjukkan adanya kegiatan jasmani yaitu merayap, merangkak, memanjat, melempar, melompat dan meloncat, memanjat, berjalan, dan berlari

Produk dari penelitian pengembangan ini yaitu sebuah buku panduan praktis yang dinamakan pembelajaran gerak dasar anak usia 2-4 tahun. Buku tersebut dibuat berdasarkan karakteristik pada setiap aktivitas fisik yang disesuaikan dengan ciri anak di usianya, pertumbuhan dan perkembangan motorik sehingga terbentuk model belajar gerak. Aktivitas yang sudah dikenal oleh anak, serta kegiatan yang menyenangkan bagi anak agar dapat merangsang pertumbuhan dan perkembangan pada usianya.

Saran pemanfaatan berdasarkan penelitian pengembangan ini yaitu agar model pembelajaran yang dikembangkan dapat digunakan guru PAUD sebagai salah satu bentuk acuan dalam mengajarkan gerak dasar pada anak usia 2-4 tahun yang lebih menyenangkan. Untuk dapat mewujudkan hal tersebut, perlu ditingkatkan persiapan sebelum mengajar gerak, kemauan dan kreativitas guru untuk senantiasa meningkatkan kualitas pembelajaran dengan berbagai bentuk variasi belajar gerak yang menyenangkan sehingga dapat merangsang pertumbuhan dan perkembangannya. Pada pelaksanaan pembelajaran tentunya dapat dipersiapkan dengan matang oleh seorang guru.

Untuk mengatasi keterbatasan fasilitas dan alat, guru harus kreatif dan dapat memaksimalkan alat yang dimiliki oleh sekolah serta memanfaatkan alat yang sudah tidak terpakai. Contohnya, botol aqua bekas untuk target sasaran pada permainan bowling, berjalan di atas tali bisa menggunakan tali rafia dll.

Diseminasi hasil penelitian ini dapat dilakukan melalui seminar-seminar, dan dalam bentuk pembuatan artikel. Selain itu, dapat juga dilakukan melalui penelitian tindakan kelas ataupun eksperimen dengan melibatkan guru PAUD untuk mengetahui bukti nyata dari produk pembelajaran.

Untuk pengembangan produk lebih lanjut, selain berupa buku panduan permainan, produk penelitian dapat dibuat dalam bentuk $\mathrm{CD}$ pembelajaran. 


\section{Daftar Pustaka}

Adi, W, dkk. (2007). Pendidikan taman penitipan anak/kelompok bermain. Yogyakarta: PGTK FIP UNY.

Allen dan Lynn. (2010). Profil perkembangan anak: prakelahiran hingga usia 12 tahun (terjemahan dalam bahasa Valentino). Jakarta. Indeks.

Borg, Walter R. dan Gall, Meredith, Damien. (1983). Educational research: An introduction $\left(4^{\text {th }} e d\right)$. New York: Longman Inc.

Gabbard, Carl. et all. (1987). Physical education for children: Building the foundation. New Jersey: Prentice-Hall, Inc.

Joyce, B. \& Weil, M. (2004). Model of teaching. USA: Pearson Education, Inc.

Kogan, S. (2004). Step by step a complete movement education curriculum. USA: Human Kinetics.

Lumintuarso, Ria. (2011). Pembinaan multilateral dalam pendidikan jasmani dan olahraga prestasi. Disertasi Doktor, tidak diterbitkan, Jakarta. Universitas Negeri Jakarta.

Malina, Robert M, Bouchard, Oded. (2004). Growth, maturation, and physical activity. USA. Human Kinetics.

Mardapi, Djemari. (2012). Pengukuran penilaian dan evaluasi pendidikan. Yogyakarta. Nuha Medika.

Rahyubi, H. (2012). Teori-teori belajar dan aplikasi pembelajaran motorik. Bandung: PT. Nusa Media.

Schmidt, Richard A. (2005) Motor control and learning. Los Angeles: Human Kinetics.

Sagala, S. (2012). Konsep dan makna pembelajaran. Bandung: Alfabeta.

Sukadiyanto. (April 2012). Prinsip pembelajaran fisik motorik pada anak usia dini. Pelatihan pembelajaran fisik motorik bagi guru TK se-DIY. Yogyakarta: Pascasarjana UNY 